\title{
Komodifikasi Upacara Religi Dalam Pemasaran Pariwisata
}

\author{
Dhyah Ayu Retno Widyastuti \\ Program Studi Ilmu Komunikasi \\ Universitas Atma Jaya Yogyakarta
}

\begin{abstract}
Development of tourism program is basically done as an effort to support income sources. Policy of tourism is a key factor in its. Facts showed that the policy has not been fully aligned to the local societies. Commodification of religious ceremony is a form of marketing process undertaken to attract tourists. Critical theory approach is used which the implications can be explored through the political economy perspective in the case studies. The results showed that policies of tourism lead to economic political activities in the form of commodification of religious ceremony. Hindu's communities as an "object" of tourism policy implementation.
\end{abstract}

Key Words: religious ceremony; commodification; political economic; critical theory.

\section{Pendahuluan}

Pariwisata masih menjadi icon sebagai sumber pendapatan daerah yang cukup besar hingga saat ini. Sejak pemberlakuan kebijakan otonomi daerah memberikan ruang gerak bagi daerah untuk mengeksploitasi sumber daya daerah yang dimilikinya dalam meningkatkan Pendapatan Asli Daerah. Pariwisata bisa dikatakan sebagai "magnet" yang mampu menarik kunjungan wisatawan. Apresiasi yang tinggi terhadap objek wisata akan muncul melalui penggalian makna yang lebih dalam terhadap objek yang ada, lalu mensosialisasikan kekayaankekayaan makna yang terkandung dalam objek kepada pihak lain, menciptakan berbagai event untuk memperkaya makna sehingga mampu untuk meningkatkan persahabatan dengan pihak lain, maupun untuk tujuan yang lebih ekonomi seperti peningkatan pendapatan, memperluas lapangan kerja (Kasman, 2006).
Berbagai upaya dilakukan pemerintah daerah untuk lebih mengoptimalkan keberadaan potensi pariwisata yang sudah ada. Program kebijakan pengembangan pariwisata pun mulai diberlakukan. Seperti halnya dengan meningkatkan jumlah atraksi wisata melalui pencarian dan pembukaan objek wisata baru, penambahan fasilitas dan penambahan kerja sama dalam bidang pariwisata.

Ironisnya fenomena yang menonjol terjadi pada upacara religi. Upacara religi merupakan kebudayaan yang lebih bersifat sakral selanjutnya dikemas sebagai suatu atraksi wisata. Kebudayaan lokal yang dijadikan sebagai komoditas pariwisata. Dalah hal ini, kebijakan program pariwisata pemerintah daerah kurang memperhatikan dan tanggap terhadap kondisi masyarakat lokal. Ekspresi kebudayaan lokal tersebut cenderung dimodifikasi agar sesuai kebutuhan pariwisata sehingga dapat 
dijual kepada wisatawan. Masyarakat lokal seolah hanya menjadi pelaku wisata (Negara, 2008, dan Suastika, 2008) dan hanyut dalam dekapan dominasi ataupun hegemoni kaum kapitalis.

Dalam konteks pemasaran pariwisata tentulah memunculkan kegairahan di satu pihak, namun di pihak lain tidak pelak akan berhadapan dengan konsekuensi-konsekuensi yang tentunya harus disikapi secara bijaksana. Tinjauan kritis terhadap kebijakan program pariwisata menjadi sangat penting sehingga program kebijakan dilaksanakan secara proporsional.

Tulisan ini didasarkan pada suatu proses penelitian yang mendasarkan diri pada studi kasus (Yin, 1987) di Candi Ceto, Kabupaten Karanganyar, Propinsi Jawa Tengah dengan menggunakan pendekatan kritis melalui telaah politik ekonomi.

\section{Metodologi Penelitian}

Kajian terhadap industri pariwisata memang menarik dilakukan dan dibahas baik pada tataran konseptual, metodologis, dan praktis. Aspek menarik dari penelitian penulis adalah penelitian studi kasus dengan pendekatan kritis melalui perspektif politik ekonomi.

Penelitian dilakukan di kompleks Candi Ceto, Kabupaten Karanganyar dimana penelitian ini berusaha menggali informasi mengenai satu kasus atau yang merupakan rangkaian yaitu komodifikasi upacara religi dalam kemasan pariwisata oleh Dinas Pariwisata Kabupaten Karanganyar atau biasa dikenal sebagai studi kasus tunggal (Sutopo, 2002:112). Studi kasus merupakan strategi yang lebih cocok bila pokok pertanyaan suatu penelitian berkenaan dengan how dan why atau bagaimana dan mengapa (Yin, 1987;9). Pada penelitian ini, karena permasalahan dan fokus penelitian sudah ditentukan maka penelitian ini disebut studi kasus terpancang (Sutopo,2002:113).

Metode kualitatif digunakan penulis dimana penelitian sebagai prosedur pemecahan masalah yang diselidiki dilakukan dengan menggambarkan keadaan atau objek penelitian (seseorang, lembaga, masyarakat, dll) pada saat sekarang berdasarkan faktafakta yang tampak atau sebagaimana adanya (Nawawi, 1998: 31). Data yang dikumpulkan terutama berupa katakata, kalimat atau gambar yang memiliki arti lebih daripada sekedar angka atau frekuensi (Sutopo,2002:35). Menurut Kirk \& Miller (dalam Moleong, 2002: 3), metode ini merupakan salah satu tradisi dalam ilmu pengetahuan sosial yang secara fundamental bergantung pada pengamatan manusia. Oleh karena itu pada setiap tahapan proses penelitian, penulis menggali informasi melalui observasi dan keikutsertaan dalam setiap kegiatan yang dilaksanakan di Candi Ceto hingga memperoleh informasi berkaitan dengan persoalan dalam studi kasus yang ingin dijawab.

\section{Literatur Review}

\section{Upacara Religi dan Pariwisata}

Sistem religi merupakan satu dari tujuh unsur kebudayaan sebagaimana diungkapkan Koentjaraningrat (1990). Istilah "religi" dipakai untuk menyebut istilah agama karena dianggap lebih netral. Sistem religi merupakan suatu agama, hanya bagi penganutnya. Koentjaraningrat (2004) menyebutkan bahwa setiap religi merupakan suatu sistem yang terdiri dari empat komponen yaitu emosi keagamaan, sistem keyakinan, sistem upacara religius, 
kelompok keagamaan.

Sebagai komponen sistem religi, sistem upacara religius, bertujuan untuk mencari hubungan antara manusia dan Tuhan, dewa-dewa atau makluk halus yang ada di alam gaib. Sistem upacara keagamaan ini melaksanakan, melambangkan, berbagai konsep yang terkandung dalam sistem kepercayaan. Sistem kepercayaan merupakan wujud kelakuan atau pengejawantahan agama. Seluruh sistem upacara itu terdiri dari aneka ragam upacara-upacara yang bersifat harian, musiman atau kadangkala. Masing-masing upacara terdiri dari kombinasi berbagai unsur upacara seperti berdoa, bersujud, bersaji, berkorban, makan bersama, menari, drama suci, berpuasa, bersemedi, dan bertapa. Upacara-upacara dan tata urutan unsur-unsur tersebut sudah tentu buatan manusia dahulu kala, dan merupakan ciptaan akal manusia. Apalagi peralatan upacara seperti gedung pemujaan, masjid, gereja, pagoda, patung-patung dewa. Semua itu adalah bagian dari kebudayaan.

Keempat komponen tersebut sudah tentu terjalin erat satu dengan yang lain menjadi suatu sistem yang terintegrasi secara bulat. Berdasar uraian diatas maka jelaslah upacara religi merupakan bagian yang sangat penting sebagai penghubung antara komunikasi alam manusia dan komunikasi lahir batin dan tidak mungkin dihilangkan.

Dalam satu sisi yang berbeda, pariwisata justru mengarah pada kepuasan manusia secara duniawi. Pariwisata merupakan suatu kegiatan yang sangat terkait dengan masalah ekonomi, sosial, budaya, keamanan, ketertiban, institusi sosial yang mengaturnya maupun lingkungan alam,. Studi kepariwisataan ini pun dikembangkan dengan pendekatan yang bersifat multi disiplin atau multidisciplinary approach (Lickorish, 1997) dalam upaya memenuhi kepuasan pengunjung. Menurut Pendit (2002), terdapat tiga kebutuhan utama yang harus dipenuhi oleh suatu daerah tujuan wisata adalah: memiliki atraksi atau objek menarik; mudah dicapai dengan alat-alat kendaraan; menyediakan tempat untuk tinggal sementara

Segala upaya dilakukan untuk memunculkan motivasi perjalanan wisata. menurut Murphy (1985) bahwa motivasi pariwisata diantaranya adalah cultural motivation (motivasi budaya), yaitu keinginan untuk mengetahui budaya, adat, tradisi, dan kesenian daerah lain. Sedangkan Oka A. Yoeti (1990) membagi jenis-jenis pariwisata berdasarkan kelompok tertentu. Satu diantara berbagai jenis tersebut adalah pariwisata menurut objeknya yaitu religius rourism, suatu perjalanan wisata yang dilakukan untuk menyaksikan upacara-upacara keagamaan. Pariwisata yang sekarang mengalami kemajuan dan banyak diminati pengunjung adalah pariwisata yang berbasiskan budaya dan alam yang dikenal dengan heritage tourism. Heritage tourism menawarkan kesempatan untuk menikmati tradisitradisi di masa lampau. Wisatawan masa kini menggunakan intelektualitas dan imajinasinya untuk menerima dan mengkomunikasikan pesan yang ada pada warisan tersebut dan mengkonstruksi pandangannya terhadap tempat-tempat bersejarah.

Pariwisata itu sendiri tidak dapat dilepaskan dari kegiatan-kegiatan politik suatu negara dimana industri pariwisata itu dijalankan. Kenyataannya hubungan antara politik dan pariwisata itu tercermin 
dalam kegiatan aparatur dan organisasi pemerintah dalam keseluruhannya serta bentukanggapan umum yang dituangkan dalam bentuk peraturan-peraturan, norma-norma, syarat-syarat, laranganlarangan dan sebagainya yang kemudian dipercayakan pada instansi, badan, organisasi untuk melaksanakan segala tugas yang terumuskan di dalamnya serta memberi interpretasi kepadanya sehingga terwujud fasilitas-fasilitas yang dibutuhkan dalam memajukan industri pariwisata dalam keseluruhannya sehingga timbullah kebijaksanaan pariwisata (policy of tourism).

Kebijakan pariwisata adalah segala sesuatu tindakan instansi pemerintah dan badan atau organisasi masyarakat yang mempengaruhi kehidupan kepariwisataan itu sendiri (Pendit, 2002). Akibat-akibat yang ditimbulkan oleh adanya tindakan-tindakan politik pemerintah dalam bidang pariwisata ada kalanya menggembirakan sebab memberi stimulan, tetapi mungkin pula mengecewakan sebab menghalanghalangi. Adapun langkah kebijaksanaan pariwisata tidak bisa dipisahkan dengan bidang-bidang antara lain politik industri, politik pengangkutan, politik keuangan, politik perdagangan, politik kebudayaan, politik sosial, politik luar negeri, dan politik dalam negeri.

Diberlakukannya

undangundang Nomor 32 Tahun 2004 tentang Pemerintahan Otonomi Daerah, kewenangan pengelolaan pariwisata berada di tangan pemerintah kabupaten, Pemerintah Daerah Tingkat II. Maka arah kebijakan masing-masing kabupaten berlainan. Dalam tulisan ini mengacu pada arah kebijakan pemerintah kabupaten yang tidak terlepas dari visi misi yang telah ditetapkan.

\section{Budaya dalam Perspektif Politik Ekonomi}

Teori kritis menyelidiki kondisikondisi sosial untuk mengungkapkan pengaturan-pengaturan yang merusak, biasanya tersembunyi di balik peristiwa sehari-hari (Littlejohn, 2001). Penelitian kritis bertujuan mengungkapkan caracara dimana kepentingan-kepentingan yang berbenturan dan dimana konflikkonflik diselesaikan dengan keuntungan kelompok-kelompok tertentu terhadap yang lain. Proses dominasi seringkali tersembunyi dari pandangan, dan teori kritis bertujuan mengungkap prosesproses ini. Teori Kritis beranggapan bahwa yang terpenting bukan bagaimana "fakta" diinterpretasikan, melainkan bagaimana fakta atau realitas dipahami secara holistik, dan menjadi bagian bersama dari subjek yang terlibat (Narwaya, 2006).

Teori Kritis tidak berupaya mencari kebenaran sebuah fakta, apalagi membiarkanya dalam kondisi apa adanya. Teori ini berupaya menjelaskan fakta dalam rangka emansipasi terhadap kondisi masyarakat. Capaian akhir dari kesadaran kritis adalah sebuah perubahan yang signifikan terhadap kebutuhankebutuhan yang konkret dapat dirasakan masyarakat, dimana masyarakat adalah sumber sekaligus pelaku perubahan itu sendiri.

Dalam pendekatan kritis struktural, proses dominasi, dimana sekumpulan pemikiran merongrong atau menekan yang lain dikenal sebagai hegemoni (Littlejohn, 2001). Itu merupakan proses melalui mana sebuah kelompok menjalankan kepemimpinan atas yang lain. Hegemoni merupakan proses halus untuk membuat kepentingan kelompok bawahan tunduk pada kelompok 
dominan.

Dalam konsep industri budaya, mahzab Frankfurt mengacu pada cara dimana hiburan dan media massa menjadi industri pada masa kapitalisme pasca Perang Dunia II baik dalam mensirkulasi komoditas budaya maupun dalam memanipulasi kesadaran manusia. Marx memahami bahwa ideologi seperti halnya agama adalah candu bagi massa. Industri budaya beroperasi sepanjang prinsip yang sama. Namun terdapat dua perbedaan. Pertama, agama adalah doktrin terstruktur, yang ditata dalam satu kitab atau kode. Ini dapat dipelajari dan dikritisi. Kedua, agama menjanjikan kelegaan dari ketakutan dalam kehidupan setelah mati (Agger, 2003).

Menurut teoritisi kritis, bahwa budaya bukan lagi sesuatu yang terpisah, satu wilayah ekspresi dan pengalaman di mana pemahaman kritis dapat diraih. Melalui ilusi praktis, budaya menahan komodifikasinya sendiri, merepresentasikan ekspresi dan pengalaman yang tidak terkontaminasi oleh logika kapital dan mempertahankan kemampuan untuk berbeda dan berpikir kritis. Industri budaya telah membantu memanipulasi kesadaran sehingga memperpanjang kapitalisme yang dulu kemundurannya diharapkan Marx. Meskipun Marx menyatakan budaya dapatberfungsi secaraideologis (misalnya analisis tentang agama), dia menakar secara lebih berat dalam analisi ekonomi politik kapitalismenya. Argumen industri budaya tidak mematahkan kerangka teoritis dasar Marx, yang mengaitkan logika kapital dengan hubungan manusia yang difetisisasi-komoditaskan, membuat keuntungan melalui hubungan manusia yang dimistifikasi sehingga dialami sebagai sesuatu yang alami, pengaturan yang seolah-olah alami, yang disebut Marx sebagai fetisisme komoditas (Johnson, 1983).

Inilah yang menandakan proses industrialisasi dari budaya yang komersialisasi yang mengendalikan sistem. Industri budaya ditampilkan dalam ciri yang sama dengan produk lainnya dalam produksi massa yaitu komodifikasi, stardarisasi, dan massifikasi. Sebagaimana ungkapan Kellner (1995), bahwa komodifikasi awalnya ditentukan adanya standarisasi oleh sekelompok pemilik modal dalam industri budaya dengan parameter hukum pasar, dimana produk yang dianggap standar jika berlaku di pasar dan memungkinkan proses produksi budaya dalam jumlah yang massif yang mengakibatkan segala jenis budaya apapun dijadikan suatu komoditas.

Dalam perspektif politik ekonomi, komodifikasi biasanya mengejawantah dalam bentuk-bentuk komersial dimana negara menempatkan bentuk aturan didasarkan standar pasardan menetapkan aturan pasar. Komodifikasi menjadi alat utama untuk mengubah relasi sosial menjadi relasi ekonomi (Curran, 1996). Sebagaimana pendapat Mosco (1998), "Commodification processes analyzed included media content as commodity, the sale of audiences to advertisers, the collection and sale of personal information, and intrusion of advertising into public spaces". Jadi, komodifikasi budaya (upacara religi) berarti mengubah upacara religi menjadi produk yang dapat dipasarkan. Komodifikasi yang didukung oleh media massa dalam bentuk komunikasi pemasaran (periklanan) dapat mengancam berbagai bentuk norma, nilai, identitas dan simbol-simbol budaya lokal. Lambat laun nilai-nilai budaya lokal seperti juga yang terdapat dalam upacara religi tersebut, akan mengalami 
pergeseran dan bisa dimungkinkan digantikan oleh nilai-nilai budaya baru.

Ideologi dalam hal ini dapat dikatakan sebagai distorsi realitas. Ideologi adalah pikiran yang terorganisir, yakni nilai, orientasi, kecenderungan yang saling melengkapi sehingga terbentuk perspektif-perspektif ide yang diungkapkan melalui komunikasi dengan media teknologi dan komunikasi antar pribadi (Lull, 1995). Dalam teori sosial ideologi didefinisikan menurut bagaimana informasi dipergunakan oleh suatu kelompok sosial ekonomi ("kelas berkuasa' dalam istilah Marxis) untuk mendominasi kelompok lainnya. Ideologi hadir dalam struktur sosial sendiri dan muncul dari praktek-praktek aktual yang dilaksanakan institusi dalam masyarakat.

Sejalan dengan pemikiran Karl Marx, ideologi dimengerti oleh Karl Marx sebagai, "Ajaran yang menjelaskan suatu keadaan, terutama struktur kekuasaan, sedemikian rupa sehingga orang menganggapnya sah, padahal jelas tidak sah. Ideologi melayani kepentingan kelas berkuasa karena memberikan legitimasi kepada suatu keadaan yang sebenarnya tidak memiliki legitimasi" (Suseno, 2001, Kartono, 2005). Sebuah ideologi merupakan sekumpulan pemikiran yang membentuk struktur realita suatu kelompok, sebuah sistem perwakilan atau sebuah kode dari pengertianpengertian yang mengatur bagaimana individu dan kelompok memandang dunia. Menurutnya, sejumlah gagasan dapat didistorsikan atau realitas mampu "dibalikkan" sebab realitas itu sendiri selalu berubah-ubah. Suatu distorsi yang berasal dari realitas sosial yang sesungguhnya terjadi. Gagasam dari kelas yang berkuasa menjadi gagasan yang dominan karena mempunyai kekuatan material dalam masyarakat yang dengan sendirinya akan menentukan kekuatan intelektualnya. Sebaliknya kelompok bawah akan dengan sendirinya menyerah dan tunduk terhadap gagasan-gagasan yang diproduksi oleh kelas berkuasa tersebut.

Dalam Teori Kritis, realitas tidak dimaknai sebagai sesuatu yang apa adanya dan terpisah dari konstruksi sejarah, sosial, ekonomi, politik dan budaya. Realitas selalu terbangun dari hasil kontradiksi-kontradiksi yang terbentuk dalam masyarakat. Sebuah fakta atau realitas tidaklah stagnan dan berhenti, melainkan selalu bergerak, berubah dan berkembang. Dengan demikian sasaran utama pendekatan kritis adalah untuk mengekspos bagaimana ideologi dari kelompok yang kuat dipertahankan dengan sungguhsungguh dan bagaimana ideologi tersebut bisa ditentang untuk menumbangkan sistem kekuasaan yang menekan hak-hak kelompok tertentu.

\section{Hasil Penelitian}

\section{Deskripsi Upacara Religi Saraswati}

Penelitian dilakukan di Candi Ceto, yaitu sebagai tempat berlangsungnya upacara religi Saraswati. Pelaksanaan upacara melibatkan masyarakat, aparat pemerintah Kabupaten Karanganyar. Ceto merupakan satu dari lima dukuh yang berada di Desa Gumeng, Kecamatan Jenawi, Kabupaten Karanganyar. Ceto mempunyai jumlah penduduk yang paling banyak diantara keempat dukuh lainnya, yaitu sejumlah 392 jiwa. Berdasarkan data Monografi Desa Gumeng, Kec. Jenawi, (2008), mayoritas penduduk Ceto beragama Hindu (382 orang) dengan mata pencaharian dominan sebagai petani secara spesifik 
PNS (1 orang), Petani (301 orang), Pelajar (90 orang) dengan tingkat pendidikan di atas Diploma sebanyak 2 orang. Penghasilan rata-rata penduduk Ceto berkisar Tiga Ratus Ribu sampai dengan Satu Juta per bulan.

Candi Ceto merupakan satu diantara objek wisata candi yang cukup memadai dan mendapat perhatian lebih dari pemerintah kabupaten. Di sekitar Candi Ceto lingkungan alamnya sangat mendukung, dengan pemandangan alamnya yang indah di sekitarnya ada perkebunan teh serta hutan lindung. Adanya perkebunan teh, dikembangkan sebagai paket wisata agrobisnis, memetik teh, outbond, dan sebagainya.

Candi Ceto sebagai hasil budaya yang bersifat religius ditunjang dengan penduduk yang sebagian besar beragama Hindu, maka untuk pengembangan dan peningkatan kunjungan wisata, pemerintah Kabupaten Karanganyar salah satu upayanya dengan memanfaatkan upacara religi yang berlangsung oleh masyarakat setempat yaitu upacara Saraswati

Hari Raya Saraswati yaitu hari Pawedalan Sang Hyang Aji Saraswati, (istilah nama Tuhan Yang Maha Esa dalam agama Hindu) dalam kekuatannya menciptakan ilmu pengetahuan dan ilmu kesucian. Hari raya ini diperingati setiap enam bulan sekali yaitu setiap 210 hari, pada hari Saniscara Umanis (Sabtu Legi) Wuku Watugunung (Adiputra, 2004).

Upacara ini diselenggarakan pagi hari atau sebelum siang hari. Bagi masyarakat yang melaksanakan Brata Saraswati secara penuh, sebelum upacara Saraswati dan sebelum kelewat tengah hari (selama 24 jam) tidak diperkenankan membaca dan menulis. Seluruh umat melaksanakan secara serentak dan masyarakat Ceto upacara dilaksanakan di Puri Taman Saraswati, Candi Ceto.

Unsur-unsur dalam pelaksanaan upacara meliputi (1) upakara: canang, bunga dan kewangen, tirtha, bija, api atau dhupa, sesaji berupa buah-buahan; (2) persembahyangan: pemujaan, sembahyang, matirtha, mawija; (3) banyu pinaruh sebagai tanda berakhirnya upacara Saraswati yang dilaksanakan Minggu Paing wuku Sinta yang terdiri dari asuci laksana, nunas labaan Saraswati.

\section{Komodifikasi Upacara Religi Saraswati}

Perayaan hari raya Saraswati selanjutnya mendapat perhatian lebih dari pemerintah Kabupaten Karanganyar dalam upaya pengembangan pariwisata. Kabupaten Karanganyar telah menempatkan posisinya sebagai pintu gerbang utama untuk pergaulan regional maupun internasional. Hal ini bisa terlihat Karanganyar sudah melakukan interaksi kebudayaan secara intensif dengan Bali yang sarat dengan religi Hindu. Kontak dengan kebudayaan Bali telah memberikan semacam sentuhan impulsif untuk lebih membangkitkan potensi serta menjadi landasan bagi perkembangan kebudayaan Karanganyar di masa selanjutnya. Produk kebudayaan Kabupaten Karanganyar khususnya Candi Ceto semakin tampak berbeda dengan sebelumnya yakni melalui komodifikasi upacara religi tersebut. Hal ini ditunjukkan oleh beberapa pokokpokok temuan seperti (a) Upacara religi Saraswati pada mulanya bersifat eksklusif, tertutup dan hanya untuk kalangan terbatas khususnya umat Hindu, tetapi saat ini upacara tersebut pelaksanaannya dapat diakses secara leluasa oleh masyarakat umum; (b) Persembahan sesaji oleh masyarakat Ceto yang biasanya menggunakan 
upakara Jawa ("ubarampe" orang Jawa menyebutnya) dan sesaji berupa buahbuahan atau makanan lainnya ("pajegan" orang Hindu menyebutnya) dibuat sesuai dengan kemampuan warga, kini dibuat beraneka warna dan menarik pengunjung. Anggaran pembuatan sesaji diperoleh dari pemerintah Kabupaten Karanganyar melalui Dinas Pariwisata; (c) Guna mengurangi kejenuhan para umat selama rangkaian upacara, sebelum acara inti, persembahyangan bersama ditampilkan sebuah pertunjukan sebagai suatu atraksi wisata. Pemangku yang biasanya melakukan pemujaan lebih kurang satu jam sebelum persembahyangan bersama dimulai, kadangkala dikejarkejar untuk segera diselesaikan; (d) Adanya media komunikasi pemasaran untuk upacara religi Saraswati maupun jenis upacara yang lain di Candi Ceto seperti brosur, calender of event, dimana tampilan maupun gambar di dalamnya lebih pada atraksi yang berlangsung bukan pada gambaran upacara religi Saraswati atau pun jenis upacara yang ada di Candi Ceto; (e) Kebijakan program pariwisata Kabupaten Karanganyar mengenai pengembangan objek wisata candi memunculkan perbedaan versi tanggapan khalayak antara masyarakat lokal dan wisatawan. Jadi di satu sisi kebijakan yang dibuat oleh pemerintah Kabupaten Karanganyar tepat sasaran yakni mampu meningkatkan jumlah kunjungan wisata, namun di sisi lain kebijakan yang dilakukan perlu disikapi secara bijaksana

Sebagai satu bidang yang komplek, industri pariwisata tidak dapat dipandang hanya dari satu sisi positipnya, yaitu seperti mengharapkan datangnya perolehan pendapatan, tetapi sisi negatifnya juga harus diperhitungkan (De Kadt dalam Heru Nugroho, 2001).
Namun yang biasanya tidak langsung disadari oleh masyarakat adalah bekerjanya berbagai kepentingan di balik industri kepariwisataan baik politik maupun ekonomi. Terlebih lagi industri pariwisata yang bergulir sekarang ini pada dasarnya berkaitan dengan keterlibatan dan bertemunya berbagai kepentingan politik ekonomi banyak pihak. Oleh karena itu, pembahasan kepariwisataan tidak dapat dipahami dari onesided tetapi multidimensional dan multidisiplin.

Industrialisasi pariwisata dapat ditelaah dengan mendasarkan pada pemahaman perspektif ekonomi politik (political economy) dalam teori kritis. Ekspansi dan penetrasi pariwisata telah menimbulkan dampak negatif, yaitu mengacu pada perhitungan cost benefit, pihak mana yang lebih diuntungkan dari terselenggaranya industri tersebut. Dalam prakteknya industri pariwisata telah memainkan peran dan bertindak sebagai instrumen kapitalis. Dalam pendekatan kritis, menurut pandangan Habermas tidak ada aspek kehidupan yang bebas dari kepentingan.

Realitas dalam teori kritis, tidak dimaknai sebagai sesuatu yang apa adanya dan terpisah dari konstruksi sejarah, sosial, ekonomi, politik dan budaya. Realitas selalu terbangun dari hasil kontradiksi-kontradiksi yang terbentuk dalam masyarakat. Sebuah fakta atau realitas tidaklah stagnan dan berhenti, melainkan selalu bergerak, berubah dan berkembang. Artinya, peran ideologi menjadi dominan. Ideologi mendistorsikan realitas yang sebenarnya guna memuluskan kepentingan dari kelas yang berkuasa (the rulling class). Ideologi menjadi pemalsuan dan serentak menjadi distorsi dari realitas sosial yang sesungguhnya terjadi dalam masyarakat 
sehingga kelas yang dikuasai dapat dikelabui begitu saja (Littlejohn, 2001).

Struktur sosial yang menekan sebenarnya bersifat nyata, tetapi mereka mungkin tersembunyi dari kesadaran kebanyakan orang. Masyarakat Ceto yang mayoritas tergolong dalam ekonomi menengah ke bawah, dengan tingkat pendidikan yang masih tergolong rendah hanyut dalam hegemoni ekonomi oleh kelas berkuasa. Ini berarti masyarakat Ceto telah masuk dalam arena yang telah banyak disebut oleh pengikut kritis sebagai masyarakat kapitalis. Hal ini tidak luput dari teori budaya yang menyatakan bahwa masyarakat kapitalis didominasi oleh ideologi tertentu dari elit, kaum berkuasa. Industri budaya telah membantu memanipulasi kesadaran, karena seperti pernyataan Marx bahwa budaya dapat berfungsi secara ideologis dalam tinjauan ekonomi politik kapitalis. Industri budaya yang menguntungkan dengan mengaitkan logika kapital dan hubungan manusia yang dikomoditaskan.

Kedalamandominasitelahtenggelam dalam setiap event yang diselenggarakan di Candi Ceto bahkan dalam kehidupan sehari-hari oleh masyarakat setempat. Upacara religi Saraswati dapat diakses secara leluasa oleh masyarakat umum. Upakara Jawa ("ubarampe" orang Jawa menyebutnya) yang biasanya digunakan oleh masyarakat Ceto dan sesaji ("pajegan" orang Hindu menyebutnya) dibuat dibuat beraneka warna dan mendapat anggaran dari pemerintah Kabupaten Karanganyar melalui Dinas Pariwisata. Pada rangkaian upacara, ditampilkan sebuah pertunjukan tari yang bertemakan Saraswati dimana dapat dinikmati sebagai suatu atraksi wisata. Hal ini juga dimaksudkan sebagai suguhan kepada para pengunjung objek wisata di Candi Ceto.
Berdasar fenomena tersebut, budaya memainkan peran yang lebih nyata pada masyarakat kapitalisme. Masyarakat Ceto seolah telah terjebak dalam kegiatan rekreasional dan kultural yang masih represif karena aktivitas yang mereka lakukan hanya mengalihkan manusia dari pengenalan atas keterasingan mereka sendiri. Pemerintah Kabupaten Karanganyar melalui kebijakan Dinas Pariwisata Karanganyar melaksanakan program pengembangan pariwisata yang mencakup potensi wilayah termasuk upacara religi yang masih kental dilaksanakan oleh penduduk setempat. Promosi wisata baik melalui surat kabar, brosur, televisi lokal, sebagian besar menggambarkan aktivitas religi yang dikemas secara unik sehingga kekhasan wisata Ceto dengan citra "wisata religi' sangat menonjol. Jumlah pengunjung mengalami peningkatan sejak dilaksanakan program tersebut, secara spesifik 7.121 (2003), 18.983 (2004), 13.041 (2005), 14.088 (2006), 16.228 (2007) (Dinas Pariwisata Kab. Karanganyar, 2008) sehingga penerimaan pendapatan daerah pun meningkat. Ditinjau dari segi sosial ekonomi masyarakat bisa memperoleh lapangan kerja baru (home stay, tempat parkir, dll), akan tetapi bagaimana dengan kondisi masyarakat Ceto yang mayoritas (97\%) adalah umat Hindu, mereka seolah-olah hanya sebagai objek dari aktivitas tersebut. Dalam artian, aktivitas ini dikomodifikasikan, sehingga memberikan keuntungan kepada kapitalisme dengan menciptakan kebutuhan palsu pada saat kebutuhan banyak orang dapat dipenuhi. Adanya upacara religi yang sebagai komoditas dalam kemasan pariwisata memberi manfaat ekonomi dengan menciptakan lapangan kerja baru dan pengalihan penghasilan dari bertani menjadi 
berdagang, dan sebagainya. Penguasaan kesadaran oleh sebuah struktur yang tidak secara langsung bisa disadari oleh masyarakat. Berbagai acara maupun seminar yang diselenggarakan baik oleh instansi pemerintah bahkan yang digelar oleh masyarakat didominasi oleh pernyataan-pernyataan Dinas Pariwisata yang seolah memberi keuntungan pada masyarakat sehingga reaksi protes yang semula menjadi tujuan awal pun terhanyutkan. Seperti seminar yang diselenggarakan oleh Parisada Hindu Dharma Indonesia (PHDI) Kabupaten Karanganyar yang salah satu tujuannya mencarijalantengahataskeberadaanumat Hindu sebagai masyarakat terpinggirkan yang seolah hanya sebagai pelaku wisata, selanjutnya terdoktrin oleh pernyataanpernyataan keuntungan, manfaat yang dilontarkan Dinas Pariwisata. Protes tidak berlanjut dan pertanyaan tidak terjawab dengan memuaskan. Dapat dikatakan di sini, kapitalisme kini mendoktrin kesadaran palsu untuk meyakinkan manusia melalui industri budaya, suatu proses industrialisasi dari budaya yang diproduksi secara massif dan komersialisasi yang mengandalkan sistem melalui kebijakan dimana ditampilkan dalam produksi massa yaitu komodifikasi. Sarana upacara agama Hindu sebagai benda yang memiliki makna religius pun berubah menjadi makna ekonomis (Ariasri, 2006).

Proses komodifikasi itu sendiri tidak terlepas dari pemikiran komunikasi yang terdiri dari beberapa unsur. Dalam proses komunikasi (Schramm, 1955) terdiri dari sembilan elemen yang saling terkait. Namun dalam kegiatan tersebut terdapat tiga unsur penting yang berkaitan dengan pengaruh yang ditimbulkan. Menurut Astrid S. Susanto (1997), ketiga unsur tersebut adalah: "Alat atau media, proses dan isi yang saling berinteraksi dan secara tidak langsung akan menghasilkan pola efektivitas". Ini berarti pesan yang disampaikan melalui media tertentu akan berhubungan dengan masalah bagaimana proses produksi dan transformasi pesan tersebut. Apabila media berubah maka dengan sendirinya proses juga berubah meskipun substansi isi pesan tidak berubah. Begitu juga upacara religi Saraswati yang dikomodifikasi dalam kemasan pemasaran. Dalam masyarakat kapitalis komodifikasi melanda siapapun dan terhadap apapun. Semua cenderung menjadi objek pasar dan dikemas dalam budaya konsumen.

\section{Simpulan}

Berdasarkan pada paparan temuan hasil penelitian di atas dapat disimpulkan (1) Dalam perayaan upacara religi yang terpenting bukanlah kemeriahan dalam peringatan semata, tetapi lebih pada aktualisasi nilai-nilai yang diajarkan yang telah menjadi tuntunan bagi manusia; (2) Kebijakan pariwisata telah membawa implikasi luas, baik pada kegiatan kepariwisataan itu sendiri, maupun bagi pengelolaan lingkungan alam, sosial dan budaya sebagai sumber daya yang menjadi andalan utama dalam kegiatan pariwisata, bahkan implikasi terhadap kehidupan masyarakat melalui komodifikasi upacara religi yang merupakan salah satu rangkaian kegiatan yang dilaksanakan di kompleks pariwisata; (3) Upacara religi Saraswati dikemas sebagai komoditas pariwisata melalui bentuk kegiatan atraksi wisata yang merupakan komponen utama dalam pemasaran pariwisata. Dalam pendekatan teori kritis, perspektif politik ekonomi dapat dicirikan dengan adanya dominasi ideologi yaitu penguasaan suatu sistem oleh struktur berkuasa 
dimana suatu kebijakan membelenggu di luar kesadaran masyarakat. Masyarakat seolah merasakan perubahan kehidupan dari kebijakan yang ada, akan tetapi dalam praktek sesungguhnya kebijakan yang diterpakan dan dilaksanakan mengarah pada suatu bentuk industri pariwisata yang memainkan peran dan bertindak sebagai instrumen kapitalis, sebuah ekspansi yang mengacu pada perhitungan cost benefit dan pihak mana yang lebih diuntungkan. Kesadaran yang ada pada masyarakat bisa dibilang adalah kesadaran palsu.

\section{Penutup}

Dalam proses pengembangan pariwisata membutuhkan usaha yang kreatif guna menghadapi persaingan dari wilayah lain. Pemberdayaan potensi yang ada di objek wisata dan sekitarnya sangat penting guna mencapai hasil yang optimal. Seiring dengan persaingan yang makin ketatdalamarea pariwisata langkah apapun seolah menjadi sesuatu yang sah untuk dilakukan. Namun bagaimana ketika akhirnya merambah pada upacara religi yang notabene merupakan suatu proses sakral dijadikan sebagai sebuah atraksi. Upacara religi merupakan bagian dari sistem religi dalam unsur budaya. Budaya memang akan selalu mengalami perubahan dan itupun tidak mudah untuk dibendung. Dalam hal ini tentulah sikap bijak dan langkah yang tepat yang perlu menjadi pertimbangan. Budaya tetap akan bersifat dinamis namun dalam proses perubahannya para pelaku budaya tentunya harus bisa memilah antara potensi yang memang layak dikomoditaskan dan yang secara etis perlu dijunjung dan dihargai keberadaannya. Dalam artian kebijakan yang diberlakukan untuk pengembangan program pariwisata tentunya tanpa menciptakan kesadaran semu dan menciptakan keterpinggiran pihak tertentu.

\section{Daftar Pustaka}

Adiputra, Nengah Rudia, dkk (2004). Dasardasar Agama Hindu. Jakarta, Direktorat Jenderal Bimbingan Masyarakat Hindu dan Budha Depatemen Agama RI

Agger, Ben (2003). Teori Sosial Kritis; Kritik, Penerapan dan Implikasinya. Yogyakarta, Kreasi Wacana

Ariasri, Nyoman Reni (2006). Sarana Upacara Agama Hindu sebagai Alat Daya Tarik Pariwisata: Studi Kasus di Kawasan Wisata Nusa Dua. Jurnal Vol 6 No. 1. Universitas Udayana Denpasar.

Curran, James and Michael Gurevitch (1996). Mass Media and Society. New York, Arnold

Johnson, Pauline (1983). Marxis Aesthetics: The Foundations Within Everyday Life for An Enlightening Consciousness. London, Routhledge and Kegan Paul

Kasman, Selvi (2006). Pertunjukan Kesenian Tradisional dalam Pengembangan Pariwisata Bukit Tinggi. Jurnal Vol 6 No. 1 Periode Februari 2006. Universitas Udayana Denpasar. 4 April 2009.

Kartono, Drajat Tri(ed) (2005). Komodifikasi Budaya dalam Media Massa. Surakarta, Sebelas Maret University Press

Kellner, Douglas (1995). Media Culture; Cultural Studies, Identity and Politics Between the Modern and the Postmodern. London and New York, Routledge

Koentjaraningrat (1990). Pengantar Ilmu Antropologi. Jakarta, Rineka Cipta

----(2004). Kebudayaan, Mentalitet dan Pembangunan. Jakarta, PT. Gramedia

Lickorish , Leonard J. (1997). An Introduction to Tourism. Heinemann, Butterworth 
Littlejohn, Stephen W. (2001). Theories of Human Communication. USA, Wadsworth-Thomson Learning

Lull, James (1995). Media, Communication, Culture: A Global Approach. Cambridge UK, Polity Press

Murphy, P.E (1985). Tourism: A Community Approach. New York and London, Routledge

Narwaya, St. Guntur (2006). Matinya Ilmu Komunikasi. Yogyakarta, Resist Book

Nugroho, Heru (2001). Negara, Pasar, dan Keadilan Sosial. Yogyakarta, Pustaka Pelajar

Pendit, Nyoman (2002). Ilmu Pariwisata; Sebuah Pengantar Perdana. Jakarta, PT. Pradnya Paramita

Magnis-Suseno, Franz (2001). Pemikiran Karl Marx: Dari Sosialisme Utopis ke Perselisihan Revisionisme. Jakarta, Gramedia

Nawawi, Hadari (1998). Metode Penelitian Bidang Sosial. Yogyakarta, Gajah
Mada Unversity Press

Susanto, Astrid (1997). Komunikasi dalam Teori dan Praktek. Bandung, Bina Cipta

Sutopo, H.B. (2002). Metodologi Penelitian Kualitatif. Surakarta, Sebelas Maret University Press, 2002.

Yin, R. K (1987). Case Study Research: Design and Methods. Beverly Hills, CA.: Sage Publications

Yoeti, Oka A (1990). Pemasaran Pariwisata. Bandung, PT. Angkasa

Negara, Ketut Widiartha. Identitas dan Komoditas Budaya Lokal, 2008, April 2009. http:// widibagus.wordpress. com/2008/06/27/identitas-dankomoditas-budaya-lokal

Suastika, Made. Pemberdayaan Masyarakat Lokal Sebagai Subjek Kepariwisataan Kawasan Candi Ceto dan Candi Sukuh. Makalah. 2008, 18 Januari 2008. 